\title{
Basic Tools and Frameworks for Analyzing and Understanding Competitiveness Within the Industry.
}

By

${ }^{1}$ Enida Pulaj (Brakaj) and ${ }^{2}$ Prof. Dr. Vasilika Kume

\begin{abstract}
The relationship between competition and challenges for sustainable growth in the country, industry or a firm is an argument and a basic element for the development of policies, strategies and adaptation to strategic changes. The purpose of this paper is to review the existing frameworks for analysing and understanding competitiveness and especially their application within an industry. In order that, this initiative to study and measure the attractiveness of the industry, to develop and find the proper implementation, it is necessary to build the field and infrastructure through which it will be possible to understand and measure indicators such as attractiveness, rivalry among firms, competitive position in the industry and the strategic choices. Based on this review, it is given the way in which each industry can be studied and, above all, to test the extent of application of the model and the theory of Porter in the Albanian business environment.
\end{abstract}

Key words: competitivenes, industry, strategy, Porter`s forces

\section{Introduction}

The important objective for this paper is to provide a complete framework that helps in understanding the competitiveness, attractiveness and competitive strategies within an industry. Field of study and application will be the industry due to the development and the impact of every industry on the economic growth of the country. It is evident that, the high competitive rivalry among firms has a positive impact to the client. While a good analysis of the industry influences positively on the success of the company. Assessment of the industry attractiveness, the choice of competitive strategies by the firm and the factors that affect the growth of competitiveness of the company are the main areas of study. 


\section{Concept of competitiveness}

Despite the attention that has been devoted to the concept of competition and written literature, competition remains a vague concept because there is no single definition. According to Waheeduzzan and Ryans (1996), concluded that competitiveness could be viewed as "a cause, an outcome, and as a means to achieve the objectives" while as for other authors, understanding the competition belongs to the eyes of "spectator" which can be any of the stakeholders that surrounds or is part of the company (Flanagan et al., 2005). According to the logic of inclusive characteristics, Man et al. (2002) suggest the definition of competition through four characteristics such as: long-term orientation (focus on long-term performance than temporary possession of competitive advantage), control (continuous management of resources and capacities), relativity (company's competitive position against other rival firms) and dynamism (including dynamic processes to generate profits). According to Lu (2006), "Competition is a broad concept beyond the traditional financial indicators: profitability, productivity or market share." In the same line of thought and coherence, based on financial performance indicators, Momaya and Selby (1998), define the competition among companies within an industry as the vehicle that satisfies customer needs as a result of the combination of the product or service characteristics such as: price, quality, innovation, satisfying the needs of people, offers high levels of return and potential growth"(Momaya and Selby, 1998).

Thus, this concept is the subject of many other definitions and misinterpretations in some cases because competition is a multidimensional concept. In this context, many authors have been involved in debates about the competition, bringing a complete framework related with this dimension and the features characterizing it:

$\checkmark \quad$ There is no unique definition and hence the term is subject to misinterpretation and confusion between authors viewpoints (Porter 1990, Chaharbaghi \& Feurer 1994, Cho \& Moon 2000, Momaya 2004, Balkyte \&Tvaronavičienè 2010).

$\checkmark \quad$ According to the authors' perspectives on competition and key words used in their definitions, we can say that there are various variables that measure the level of competition among firms, industries and countries (Blake, Henricsson \& Ericsson 2005).

$\checkmark \quad$ The concept of competition extends the analysis of studies and may be applied at national, industry and firm levels (Nelson 1992, Momaya 2004).

$\checkmark \quad$ The factors that influence competitiveness change with time and context (Chaharbaghi \& Feurer 1994, Cho \& Moon 2000).

$\checkmark \quad$ Competition is seen as the promoter of the process through which assets may be transformed into performance. Since the definition and measurement of the level of competition varies, Buckley et al.1988 distinguished three different dimensions in order to understand and explain the competition: the ability to perform well, providing resources and management process. In the coming years, this view of competition, developed from the World Economic Forum (WEF) and the International Institute for Management Development (IMD), was published in the periodical report 1993 World Competitiveness Report as formula of competition in all the world: Assets $\times$ Processes $=$ Performance. 
Despite that, there is no unique definition of competition; this concept is an important part of management and economic analysis, together with other indicators such as profitability, market share or productivity. Thus, the competition has been and remains an attractive concept for different levels of study including firm level competitiveness, industry (micro level) and national (macro level) (Nelson, 1992).

\section{The five competitive forces model conducting industry analysis. Pros and Cons!!!}

The industry is arena in which competition takes place. In this environment, there are a large number of factors, both with the competitive forces that structure the industry, determine the intensity of competition, the ability of the organization to be positioned against its rivals and affect the profitability of the company.

Industry analysis model proposed by Porter, takes into account the 5 forces: (1) competitive rivalry among firms, (2) threats of new entrants, (3) threats of substitute product or service, (4) the bargaining power of suppliers and (5) bargaining power of buyers.

The rivalry among firms. It is important for firms to increase their knowledge and understanding level of competition within the industry. It seems that the rivalry between firms resembles a game for a better position, using competition tactics through pricing or laying new products.

Threat of new entrants. The firms' number is the main indicator that shows the degree of concentration and performance within the industry. In the long run the number of competing firms is influenced by the ease with which they can enter and exit from the market. The new entrants threats depends on appropriate entry barriers as well as the new firms expected reaction from existing companies in the industry

The bargaining power of suppliers and buyers. These two forces can be considered together because they are closely related to each other because of the existence of the company simultaneously in the role of the supplier and the buyer. According to the Porter model, it is important that, from the used strategy, the company have to establish a balance between power suppliers and power purchasers.

Suppliers. The selection of suppliers is an important factor for the success of the company (Marvin \& et al, 2004; Lasch \& Janker, 2005; Shahroudi \&Rouydel, 2012) because the quality and cost of products / services that the company offers is directly connected with quality and cost of products/services purchased from suppliers. The supplier selection is one of the critical activities for the company due to (1) the number of suppliers and their diversity, (2) the cost of raw materials which manufacturing companies of up to $70 \%$ of product cost (Demirtas \& Ustun , 2008), (3) the impact that they submit to the performance of the company (Aguezzoul \& Lade 2007). The bargaining power of suppliers refers to the ability to change easily the input prices and reducing the quality of products and services they offer.

The bargaining power of buyers. According to Porter (1980), the buyers influence the industry through their ability to impose low prices. The power of buyers depends on the following circumstances: the number of buyers, the cost to change the supplier, the 
standardization or differentiation of the requiring product, the raw material cost occupies a considerable part of the total cost, the level of information.

Substitute products. Firms in an industry can compete with firms in other industries which offer substitute products. Customers often feel more comfortable using the substitute product as the main product and leaving the company's product as a substitute or even completely neglected.

Under the highlight of this factors analysis, the level of competitive forces influence determines the intensity of competition in every industry. As a result, the profitability and attractiveness of investing in each of the industries stand in inverse relation with the strength of each model force. The greater the power of factors is, the smaller the expected profitability is.

According to Porter, in every industry, despite of the extent and competition intensity, regardless of what it provides or produces, there are operating 5 core competitive forces, the power and their influence varies from industry to industry, even from country to country.

Many authors are agreed with the validity of the model of five competitive forces, referring some of the basic aspects of the strategic planning process:

$\checkmark \quad$ The model helps in decision-making process related with the entry or the exit from the market in a particular industry and the comparison with competitors.

$\checkmark \quad$ Combined with the analysis of the external environment, the model serves as a forecasting tool for the industry profitability, creates scenarios and generates income for future periods.

$\checkmark \quad$ In collaboration with the statistical and dynamic analysis, the companies can identify opportunities which can follow to achieve competitive advantage.

$\checkmark \quad$ This model takes into account the demand and supply of the product/service of the rival companies as well as substitute products, the relationship between cost and production volume, market structure and company`s behavior according to the nature of the competition.

Although, the five competitive forces model was widely accepted and served as the starting point for the evolution of new theories of management, the model Porter had some criticism among which we can mention:

- The model does not include and does not take into account the strategic alliances that firms can create and the electronic connections through information systems. However, Porter (2001) explains the role of the Internet as a leading supplier of information related with customers and rival firms, without having to change the model.

- The model is suitable to be used in markets with a simple structure similar to the perfect competition but in reality it seems to be impossible to achieve this condition.

o Whittington (2001) raises questions, how Porter (1980) concentrates the industry analysis in accordance with five competitive forces, leaving aside the role of the government and the labor market.

- The Michael Porter theories $(1980,1985)$ belong to the school that industry structure and the positioning are the key elements to generate higher profits. According to Porter, the position within an industry affects maximizing opportunities to create competitive advantage. In contrast, Hax (2002), through Delta Model explains that 
greater importance should be given to the used strategy than positioning. Critics from the same author refer to the answer of the questions: Which industry do the managers of the company analyze? According to the traditional model of Porter, managers must concentrate at the industry in which they actually operate. While, according to the Delta Model, the industry analysis includes the key clients industries and this of complementary products. As a result, the nature of the industry analysis is influenced by the selection of the strategic choices of firm.

\section{The correlation between industry analysis and competitive strategies.}

How the firms compete and which are the used strategies are the important questions raised during the industry and firm behavior analysis. Understanding the behavior of the firm serves as input to improve practices related with the competition (Ormanidhi \& Stringa, 2008) in order to achieve a high performance and sustainable competitive advantage.

Competitive strategies are an important choice for every business (Allen \& Helms, 2006) to create a unique and valuable position by integrating various activities (Porter, 1996). The industry model of Porter and generic strategies are considered as important pillar between management theories through which we can explain firm behavior towards competitors in a particular industry. The competitive strategies proposed by Porter are: cost leadership, differentiation and focus.

The "low cost" strategy places strong emphasis on organizational efficiency. This strategy, known as cost leadership, includes the process by which a company is able to produce or distribute goods and services at a lower cost than competitors within the industry. Porter defines the cost leadership strategy as marketing of standard products (Porter 1985) combined with aggressive prices (Porter 1980). While, the differentiation strategy refers to the development of a unique product or service (Porter 1985, Torgovicky et al., 2005) due to the specific features. There are many ways and dimensions through which firms can differentiate their products from rival companies. Despite the way, the company achieves the competitive advantage; the important dimensions remain life expectancy and the risk of feature imitation that creates uniqueness.

Based in these strategies, the question that has sparked much debate and controversy is if the company can simultaneously apply the generic strategies. The center of this debate consists at the dilemma on the exclusion or inclusion of generic strategies between each other and their impact on firm performance. There is still confusion between "hybrid strategies" and generic strategies as there is no clear result if companies implement only cost or differentiation or if they implement both methods in different time periods. Also what is most important is the fact that they fail to present the reality of strategy implementation process in new business environment, which has different rules and procedures in comparison with other markets.

The incompatibility between costs and differentiation competitive strategies proposed by Porter developed another "strategy" such as 'stuck in-the-middle'. Thus, Porter (1980, 1985) points out that a firm that engages in each generic strategy but fails to achieve any of them is 'stuck in- the-middle. Becoming 'stuck-in-the-middle' is often a manifestation 
of a firm's unwillingness to make choices about how to compete or a lack of strategy clarity. But it is important to say, it exist a huge difference between firms that are 'stuckin-the-middle' and those that combine generic strategies (Dess and Rasheed, 1992). Thus, firms pursuing a hybrid strategy have dual emphases: they emphasize efficiency (low costs) and differentiation (Wright et al., 1991). Instead, being 'stuck-in-the-middle' would mean a non-competitive advantage with a high costs position and a low level of differentiation (White, 1986).

\section{The impact of generic strategies to the business performance}

The performance is a multi-dimensional concept, which implies multiple performance indicators. Dess \& Robinson (1984) have also studied both financial and non-financial measure of organizational performance. Although "Porter discusses performance almost exclusively in terms of return on investment" (Miller \& Dess, 1993), researchers have used a wide variety of both subjective/objective and financial/nonfinancial measures to quantify a firm's performance. However, Allen and Helms (2002) state that performance is often measured in three dimensions - effectiveness, efficiency, and adaptability, but the measurements of these dimensions has led to very little consensus in the literature regarding the linkages between firm strategy to performance. Despite the different strategies, they all aim to maximize the performance of an organization improving its competitiveness in relation to its competitors in the same competitive environment (Feurer \& Chaharbaghi, 1997). So, the generic strategies require a specific set of characteristics and resources. Cost leadership requires the construction of facilities for high production volumes, the pursuit of cost reductions through learning and experience, a strict control of costs and general expenses, cost reduction in areas such as research and development, technical support and sales force and a low cost distribution system. In differentiation, the firm `s reputation as a quality or technology leader, strong cooperation from channels, great marketing skills, product engineering and basic research are very important (Porter, 1986).

The results of some empirical researches suggest there are significant differences in the configuration of variables by organizations adopting different generic strategies. There are also significant performance differences across generic types. Starting from this point of view some of the questions raised, analysing the impact of competitive strategies over business performance are:

$\checkmark \quad$ Is there a positive relationship between the implementation of a generic competitive strategy (cost-leadership, differentiation, and combination) and firm performance?

$\checkmark \quad$ Having a clear strategy: cost-leadership, differentiation or integrated (combination) strategies will the organization perform better than those which are stuckin-the-middle?

$\checkmark \quad$ Will the integreated strategies lead to higher levels of firm performance than pure strategies?

$\checkmark \quad$ Does exist a direct relationship between the number of generic dimensions emphasized and the level of firm performance obtained? 
The firm would be in disadvantage in the competition with companies that clearly go for low cost or exclusivity, as it would not be able to develop an offer cheap enough to appeal to price-sensitive consumers, or exclusive enough to attract sophisticated ones. Since costs, prices and configurations would not be adjusted to specific targets, the profit potential would be adversely affected. Porter says that for firms that achieve both cost leadership and differentiation " $(. .$.$) the rewards are great because the benefits are$ additive (...)". In this case, however, we see the strategic choice for differentiation (premium prices) with cost leadership in the background.

\section{Concusion:}

Competitiveness is vague concept that may be defined and measured in a number of ways. The purpose of this paper is to review the existing frameworks for analysing and understanding competitiveness and especially to give a framework for its application within an industry.

Based on the review, this paper introduces a simple structure through which it will be possible to understand and measure indicators such as attractiveness, rivalry among firms, competitive position in the industry and the strategic choices. According to Porter, the joint influence of the industry`s forces determines the intensity of competition, the decision of apply strategies and average profitability

Studies have proven that, although some companies into an industry may be able to perform well if they primarily compete with the low cost competitive strategy (cost advantages, low prices), the expectations are: businesses which apply only the low cost strategy would not perform very well, despite the company`s size in their industries. The reason to justify this expectation is that companies, which choose to compete only on the basis of lower costs and prices, would have their profit margins under pressure. Consequently, after a long period of time these companies which compete solely with lower costs and prices may not appear promising.

The same conclusion we can say to companies which operate solely with differentiation strategies. Although some companies into an industry may be able to perform well if they primarily compete with the differentiation strategy, the expectations are: businesses which apply only the differentiation strategy would not perform very well, despite the company`s size in their industries. The reason to justify this expectation is that companies, which choose to compete only on the basis of differentiation, whereas not stressing cost effieciency, may be in a weak position to competitors that have lower cost positions and may offer similar outputs with a good price. It is possible that the threat of substitute products is greater for such companies.

So, companies which, simultaneously, compete with the low cost strategy and the differentiation strategy perform well, because they would likely benefit by achieving greater profit margins. With the evolution of Porter theories, the industry dynamics and the positions in the life cycle curves of products and businesses may allow the business continuity through differentiation, even with less attractive margins. In addition, the cost-benefit is applicable to any level of products, services and prices, and the firm must assess its relevance. 


\section{References}

Allen, R.S. \& Helms. M.M. (2006). Linking strategic practices and organizational performance to Porter's generic strategies. Business Process Management. Vol 12 (4), pp. 433-454.

Aguezzoul, A. \& Ladet, P. (2007). A nonlinear multi-objective approach for the supplier selection, integrating transportation policies. Journal of Modeling in Management, Vol 2(2), pp. 157169.

Balkytè, A \& Tvaronavičienè, M. (2010). Perception of competitiveness in the context of sustainable development: facets of "sustainable competitiveness". Journal of Business Economics and Management, $\mathrm{Vol}$ 11(2), pp. 341-365.

Blake, N., Croot, J., Hastings, J. (2004) Measuring the competitiveness of the UK construction industry, Volume 2. Department of Trade and Industry (DTI): Construction economics and statistics, London, pp. 1-57

Buckley, P. J., Pass, C. L. \& Prescott, K. (1988) Measures of international competitiveness: a critical survey, Journal of marketing management, Vol 4 (2), pp. 175-200.

Chaharbaghi, K. \& Feurer, R. (1994). Defining competitiveness: a holistic approach, Management Decision, Vol 32 (2), pp. 49-58.

Cho, D.S. \& Moon, C.H. (2000) From Adam Smith to Michael Porter: Evolution of competitiveness theory, World Scientific Publishing Company Ltd., Singapore, Vol 2. Retrieved on line at http://fcrm.ir/UserFiles/File/books/english/9810244312.pdf

Cho, D.S., Moon, H.C., \& Kim, M.Y. (2008). Characterizing international competitiveness in international business research: A MASI approach to national competitiveness. Research in International Business and Finance. Vol 22, pp. 175-192.

Demirtas E. A., Üstun, Ö, (2008). An integrated multi objective decision-making process for supplier selection and order allocation. International Journal of Management Science Omega, Vol 36, pp 76-90.

Dess, G. G. and A. M. A. Rasheed (1992). 'Commentary: Generic strategies . . . (D Miller)', Advances in Strategic Management, Vol 8, pp. 409-416.

Dess GG \& Robinson RB Jr. (1984). Measuring organizational performance in the absence of objective measures: The case of the privately-held firm and conglomerate business unit. Strategic Management Journal, Vol 5, pp. 265-273.

Flanagan, R., Jewell, C.A., Ericsson, S., \& Henricsson, P. (2005). Measuring construction competitiveness in selected countries, Final Report. The Research Team at the University of Reading.

Hax, A. C \& Wilde II, D. L. The Delta Project. discovering new sources of profitability in a networked economy. New York: Palgrave, 2001.

Hax, A. C. and Wilde, D. L. (2002). The Delta Model - Toward a Unified Framework of Strategy. MIT Sloan Working Paper No.4261-02. Available at SSRN: http://ssrn.com/abstract $=344580$

Henricsson, P \& Ericsson, S. (2005). Measuring construction industry competitiveness: a holistic approach. Proceedings of The Queensland University of Technology Research Week International Conference, 4-8 July 2005, Brisbane, Australia, ISBN 1-74107-101-1

Lasch, R., Janker, C. G., (2005). Supplier selection and controlling using multivariate analysis. International Journal of Physical Distribution \& Logistics Management. Vol 35 (6), pp. 409-425.

$\mathrm{Lu}, \mathrm{W}$. (2006). A system for assessing and communicating contractors' competitiveness. Doctoral dissertation, The Hong Kong Polytechnic University, China. 
Man, T.W.Y., Lau, T., and Chan, K.F. (2002). The competitiveness of small and medium enterprises: A conceptualization with focus on entrepreneurial competencies, Journal of Business Venturing. Vol 17 (2), pp.123-142.

Marvin, E., Quesada. G., Mora Monge. C. A. (2004). Determining the importance of the supplier selection process in manufacturing: a case study. International Journal of Physical Distribution \& Logistics Management. Vol. 34(6), pp. 492-504.

Miller, A., \& Dess, G. G. (1993). Assessing Porter's (1980) Model In Terms Of Its Generalizability, Accuracy, And Simplicity. Journal Of Management Studies, Vol 30 (4), pp. 553-585.

Momaya, K (2004) Competitiveness of firms: review of theory, frameworks, and models. Singapore management review, $\mathrm{Vol} 26(1)$, pp. 45-61.

Momaya, K., \& Selby, K. (1998). "International competitiveness of the Canadian construction industry: a comparison with Japan and the United states".Canadian Journal of Civil Engineering, Vol 25 (4), pp. 640-652.

Nelson, R., (1992). Recent writings on competitiveness: boxing the compass. California Management Review. Vol 34(2), pp. 127-137.

Ormanidhi, O. \& Stringa.O. (2008). "Porter's Model of Generic Competitive Strategies," Business Economics, Vol 43(3), pp. 55-65.

Porter, M. (1980). Competitive Strategy: Techniques for Analyzing industries and competitors. New York

Porter, M. (1985). Competitive Advantage - Creating and Sustaining Superior Performance, New York

Porter, M. E.(1990). The competitive advantage of nations, Macmillan, London.

Porter, M.E. (1998). The microeconomics of economic development (World Competitiveness Yearbook). Davos, World Economic Forum. Cited in article Flanagan, R., Cattell, K, \& Jewell, C.(2005). Moving from construction productivity to construction competitiveness: measuring value not output. Retrieved on line: http://n.1asphost.com/competitiveness/MOVING\%20FROM\%20PRODUCTIVITY \%20TO $\% 20$ COMPETITIVENESS.pdf

Porter, M.E. (2001). Strategy and the Internet, Harvard Business Review, March 2001.

Shahroudi, K \& Rouyde, H. (2012). Using a multi-criteria decision making approach (ANPTOPSIS) to evaluate suppliers in Iran's auto industry. International Journal of Applied Operational Research. Vol. 2, No. 2, pp. 37-48.

Torgovicky. R, Goldberg. A, Shvarts. Sh, Dayan. B.R, Onn. E, Levi. Y. Dayan.Y.B. (2005). Application of Porter's Generic Strategies in Ambulatory Health Care: A Comparison of Managerial Perceptions in Two Israeli Sick Funds. Health Care Management Review. Vol $30(1)$, p. $17-23$

Waheeduzzan, A.N.M., \& Ryans, J.K. (1996). Definition, perspectives, and understanding of international competitiveness: a quest for a common ground. Competitiveness Review: $A n$ International Business Journal incorporating Journal of Global Competitiveness. Vol 6(2). pp.7-26.

Whittington, R. (2001). What is Strategy - and does it matter? Cengage Learning EMEA

White, R.E. (1986), "Generic business strategies, organizational context and performance: An empirical investigation", Strategic Management Journal, Vol. 7, pp. 217-31.

Zhao, Zh.Y.,Zhang, Sh.Y.,Zuo, J. (2011). A critical analysis of the photovoltaic power industry in China. From diamond model to gear model. Renewable and Sustainable Energy Reviews. Vol 15, pp. 4963- 4

Wright, P., M. Kroll, H. Tu and M. Helms (1991b). 'Generic strategies and business performance: an empirical study of the screw machine products industry', British Journal of Management, Vol 2, pp. 57-65. 
